\title{
First records of Lacydonia eliasoni Hartmann-Schröder, 1996 (Polychaeta: Phyllodocida) in the European Arctic
}

\author{
Mikołaj MAZURKIEWICZ ${ }^{1 *}$, Sławomira GROMISZ ${ }^{2}$, Joanna LEGEŻYŃSKA ${ }^{1}$ \\ and Maria WŁODARSKA-KOWALCZUK ${ }^{1}$ \\ ${ }^{1}$ Department of Marine Ecology, Institute of Oceanology Polish Academy of Sciences, \\ Powstańców Warszawy 55, 81-712 Sopot, Poland \\ 2 National Marine Fisheries Research Institute, Kołtataja 1, 81-332 Gdynia, Poland \\ *corresponding author<mikolaj@iopan.pl>
}

\begin{abstract}
Lacydonia (Polychaeta: Phyllodocida) is a poorly known genus containing 16 species that are sporadically collected in low densities all over the world oceans. During three cruises (in June 2014 in Ullsfjorden, northern Norway, in January 2015 in Kongsfjorden, and in June 2012 in Smeerenburg, Svalbard) nine specimens of Lacydonia eliasoni were found on sandy and muddy sediments at depths from 180 to $350 \mathrm{~m}$. All specimens were incomplete and consisted of 10 to 29 chaetigers. This study presents the first record of the Lacydonia genus in the waters of Svalbard as well as the first record of L. eliasoni in coastal waters off northern Norway. This species has been reported previously in the Skagerrak and Trondheimsfjorden (southern Norway), our findings therefore may indicate a northward extension of its range, possibly due to climate changes.
\end{abstract}

Key words: Arctic, Spitsbergen, Polychaeta, Lacydonia, range extension.

\section{Introduction}

Modern Arctic fauna is mostly a mixture of species of Atlantic and Pacific origin that expanded their distribution via a "stepping stone" pattern of dispersal during periods of warmer climate (Renaud et al. 2015) and a small contribution of endemic species, primarily in coastal regions (Dayton et al. 1994). Arctic fauna is regarded as young, remaining in the colonization phase, and vulnerable to new species invasions. This is because stable conditions for enabling benthic communities to develop have been around for only a short time - Arctic coastal waters have been free from permanent ice-cover for only the last 6000-14000 years (Dayton et al. 1994). Species pools of Arctic seas decrease in size with increas- 
ing distance from boreal habitats (Węsławski et al. 2011). Factors that promote northward spreading of boreal species include intensification and expansion of ocean currents flowing into the Arctic (e.g. the North Atlantic-West Spitsbergen Current in the Atlantic or Alaska Coastal Current in the Pacific) and the increasing ice-free area, as well as increased primary production contributing to an increased food supply for pelagic and benthic fauna (Renaud et al. 2015). Examples of northward range extensions or species composition changes can be found among various ecological formations, e.g. zooplankton - increased contribution of smaller copepods like Oithona similis Claus, 1866 in Kongsfjorden (Hop et al. 2006) or Pacific copepods advecting through the Bering Strait into the Arctic (Nelson et al. 2009); zoobenthos - the reappearance of the blue mussel (Mytilus edulis Linnaeus, 1758) in Svalbard (Berge et al. 2005); or pelagic fish - the northward range extension and reaching of Svalbard waters by the Atlantic snake pipefish (Entelurus aequoreus (Linnaeus, 1758); Fleischer et al. 2007).

Lacydonia Marion et Bobretzky, 1875 is the only genus of Lacydoniidae Bergström, 1914, a poorly-known family that consists of 16 species listed in the World Polychaete database (http://www.marinespecies.org/polychaeta). Lacydoniids are found from the shelf to abyssal depths (up to $5690 \mathrm{~m}$, Ushakov 1972), but occur in low densities and are only sporadically collected (Blake 1994). Representatives of this genus have been reported in the Southern Ocean, western and eastern coasts of the Atlantic and Pacific Oceans, Hawaiian Islands, Skagerrak, and Mediterranean, Barents and Beaufort Seas (Fig. 1).

Lacydoniids are small worms, max. a few mm long, and built of a few segments. The body shape in dorsal view is cylindrical, with tapering anterior and posterior ends (Ushakov 1972; Blake 1994; Rouse and Pleijel 2001). They are free living polychaetes, occurring on coarse sediments, mixed substrata or rocky bottom (Rouse and Pleijel 2001). One species, L. miranda Marion et Bobretzky, 1875, was also reported to dwell among bryozoans (Uebelacker and Johnson 1984). Lacydonia species appear to be gonochoric, but nothing more is known about their reproduction (Rouse and Pleijel 2001).

In this paper we document the first observations of Lacydonia eliasoni Hartmann-Schröder, 1996 in the North Atlantic and European Arctic, namely in two Spitsbergen fjords and one fjord off the Norwegian mainland.

\section{Materials and methods}

We define the European Arctic as the area north of the Arctic Circle $\left(66^{\circ} 33.5^{\prime} \mathrm{N}\right)$ between Greenland and northwest Russia, which includes the Greenland and Barents Seas, coastal waters of the Svalbard Archipelago and the northern part of the Scandinavian Peninsula. With regards to benthic fauna within this area, the coastal and shelf waters are the best studied and mapped, 

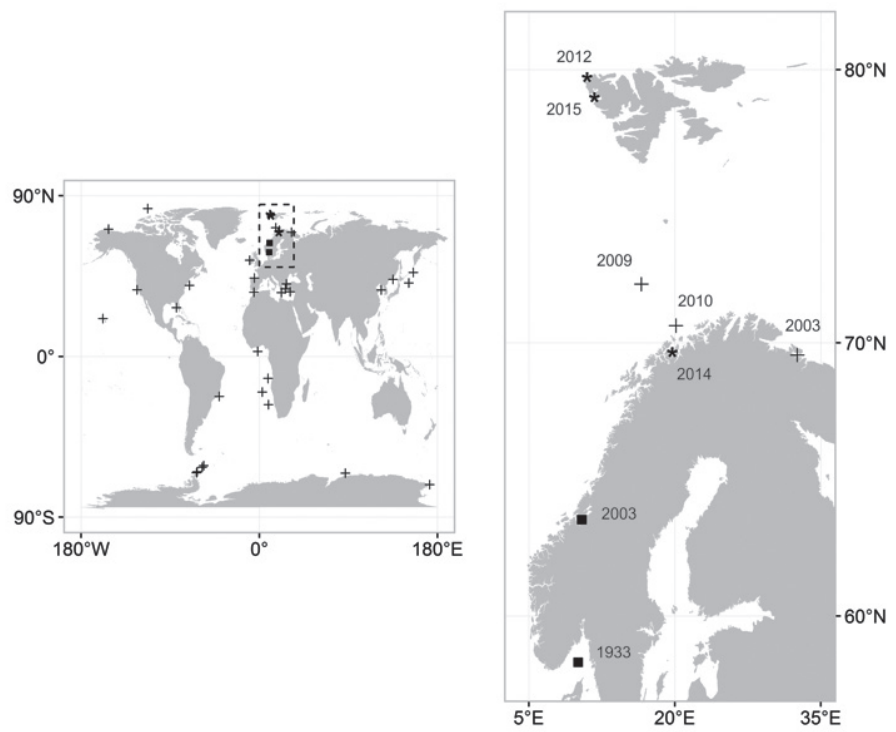

Fig. 1. Distribution of Lacydonia eliasoni records in: A) the world ocean; B) North Europe and European Arctic with catching dates: 1) this study - asterisks; 2) literature records of Lacydonia eliasoni - squares; 3) literature records of other Lacydonia species - crosses (Southern 1914; Hartman 1964; Hartman and Fauchald 1971; Ushakov 1972; Paul and Menzies 1974; Laubier 1975; Carey 1977; Uebelacker and Johnson 1984; Sardá 1985; Hartmann-Schröder and Rosenfelt 1992; Blake 1994; Borja et al. 2000; Kröger and Rowden 2008; Böggemann 2009; Anisimova et al. 2010; Fiege et al. 2010; Çinar et al. 2011; Magalhães et al. 2012; Alalykina 2013, 2015; Çinar and Dagli 2013;

Rizzo et al. 2015; http://www.mareano.no/en/download-data/imr/marbunn).

especially the waters of the Barents Sea and west Spitsbergen fjords (Palerud et al. 2004; Anisimova et al. 2010; Piepenburg et al. 2011). Polychaetes are usually a dominating taxon in benthic communities inhabiting subtidal soft-bottom habitats (e.g. Renaud et al. 2007; Thomas et al. 2008; Włodarska-Kowalczuk et al. 2012; Kędra et al. 2013).

Samples of macrozoobenthos were collected with use of a van Veen grab (0.1 $\mathrm{m}^{2}$ sampling area) during three cruises: 1) in January 2015 from board of the $\mathrm{r} / \mathrm{v}$ Helmer Hanssen in Kongsfjorden ( $\left.79^{\circ} 00^{\prime} \mathrm{N}, 11^{\circ} 40^{\prime} \mathrm{E}\right), 3$ replicate samples at each of 5 stations; 2) in June 2014 from board of the r/v Oceania in Ullsfjorden (69 $\left.47^{\prime} \mathrm{N}, 19^{\circ} 46^{\prime} \mathrm{E}\right), 3$ samples at each of 5 stations; 3) in August 2012 from board of the r/v Oceania at Smeerenburg ( $\left.79^{\circ} 42^{\prime} \mathrm{N}, 11^{\circ} 06^{\prime} \mathrm{E}\right), 3$ samples at 1 station. The samples were washed on board through a $500 \mu \mathrm{m}$ sieve and preserved in a $4 \%$ solution of formaldehyde and seawater. In the laboratory, all macroinvertebrate individuals found in samples were identified to the lowest possible taxonomical level and enumerated.

To determine the grain size distribution of the sediments at the macrofauna collection sites a Malvern Mastersizer 2000 particle size analyser was used. Data 
were processed using GradiStat 8.0. The mean particle size was characterized according to the Folk and Ward method (Folk and Ward 1957).

The distribution map of polychaetes from genus Lacydonia (Fig. 1) was prepared in R version 3.2.3 with the use of the "ggplot2" and "mapdata" packages.

\section{Results}

In total nine specimens of Lacydonia eliasoni were collected from soft sediments at depths ranging from 180 to $330 \mathrm{~m}$ (six individuals in Kongsfjorden, 1 specimen in Smereenburg and two specimens in Ullsfjorden) (Table 1).

All collected specimens were incomplete. The longest preserved specimen had 29 chaetigers, was $5.3 \mathrm{~mm}$ long and $0.3 \mathrm{~mm}$ wide. The next best preserved had 26 chaetigers (Fig. 2a) was $4.2 \mathrm{~mm}$ long and $0.5 \mathrm{~mm}$ wide. The others consisted of 10-15 chaetigers only.

Formalin preserved specimens were white to yellow in colour, with small brown pigmented spots. The prostomium was anteriorly rounded, with a width larger than its length and a near straight posterior margin (Fig. 2b). Specimens had three digitiform antennae (median antenna not visible on Fig. 2b), and two palps, eyes were absent. All of them were typified by an achaetous first segment, which was by half shorter than the next segment, with one pair of fine tentacular cirri. Specimens had three pairs of uniramous anterior parapodia, following one biramous with widely separated noto- and neuropodial rami of

Table 1

Abundance of L. eliasoni in collected samples. Station names and geographical position, depths $[\mathrm{m}]$ and sediment types are presented.

\begin{tabular}{|c|c|c|c|c|}
\hline Station/sample & $\begin{array}{c}\text { Depth } \\
{[\mathrm{m}]}\end{array}$ & $\begin{array}{l}\text { Sediment type } \\
\text { (Textural } \\
\text { group) }\end{array}$ & $\begin{array}{l}\text { Geographical } \\
\text { position }\end{array}$ & $\begin{array}{l}\text { Abundance } \\
\text { [ind. } 0.1 \mathrm{~m}^{-2} \text { ] }\end{array}$ \\
\hline Kongsfjorden St. 1A & \multirow{2}{*}{307} & \multirow{2}{*}{ gravelly mud } & \multirow{2}{*}{$\begin{array}{l}78^{\circ} 58.60^{\prime} \mathrm{N} \\
11^{\circ} 43.44^{\prime} \mathrm{E}\end{array}$} & 2 \\
\hline Kongsfjorden St. 1B & & & & 1 \\
\hline Kongsfjorden St. 2A & \multirow{2}{*}{305} & \multirow{2}{*}{ sandy mud } & \multirow{2}{*}{$\begin{array}{l}78^{\circ} 59.10^{\prime} \mathrm{N} \\
11^{\circ} 31.22^{\prime} \mathrm{E}\end{array}$} & 1 \\
\hline Kongsfjorden St. 2B & & & & 1 \\
\hline Kongsfjorden St. 3 & 350 & sandy mud & $\begin{array}{l}79^{\circ} 00.62^{\prime} \mathrm{N}, \\
11^{\circ} 26.66^{\prime} \mathrm{E}\end{array}$ & 1 \\
\hline Smeerenburg & 182 & sandy mud & $\begin{array}{l}79^{\prime} 41.14^{\prime} \mathrm{N}, \\
11^{\circ} 09.59^{\prime} \mathrm{E}\end{array}$ & 1 \\
\hline Ullsfjorden St. 1A & \multirow{2}{*}{180} & \multirow{2}{*}{$\begin{array}{l}\text { slightly } \\
\text { gravelly } \\
\text { muddy sand }\end{array}$} & \multirow{2}{*}{$\begin{array}{c}69^{\circ} 53.48^{\prime} \mathrm{N} \\
19^{\circ} 56.99^{\prime} \mathrm{E}\end{array}$} & 1 \\
\hline Ullsfjorden St. 1B & & & & 1 \\
\hline
\end{tabular}



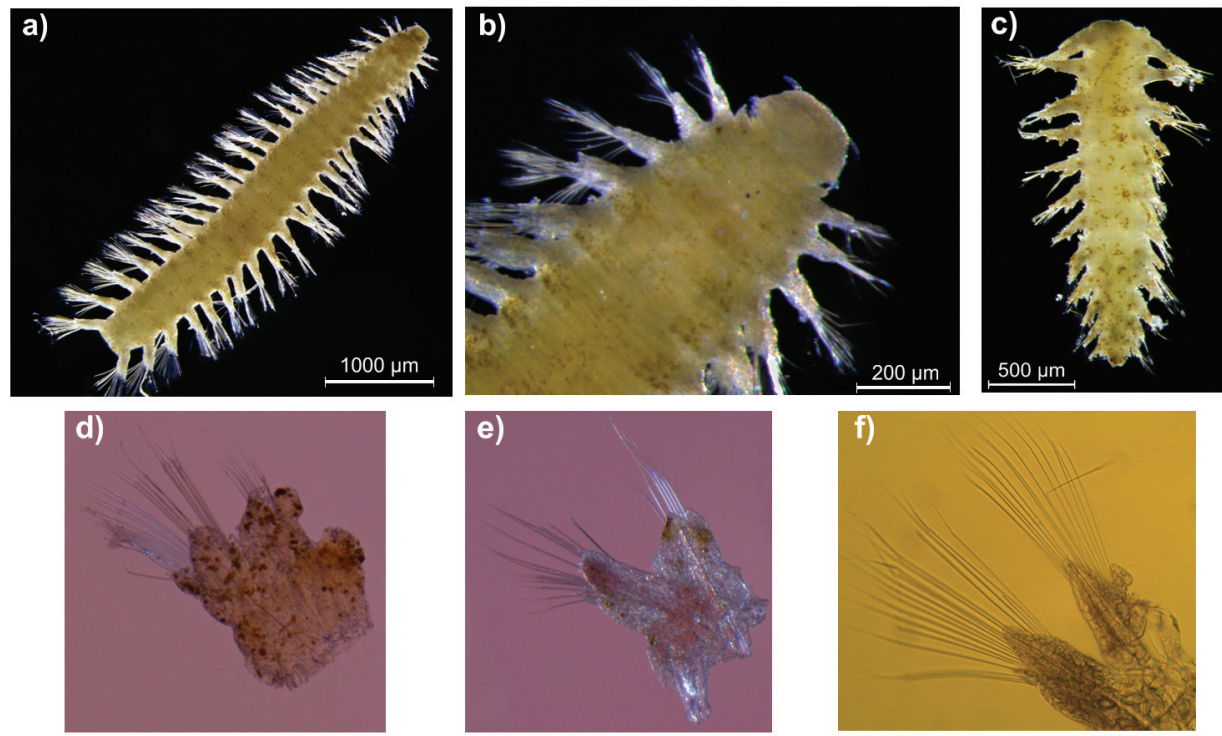

Fig. 2. Lacydonia eliasoni collected in Ullsfjorden: A) individual lacking posterior part of body; B) anterior part, dorsal view; C) posterior part; D) $8^{\text {th }}$ chaetiger; E) $13^{\text {th }}$ chaetiger; F) $24^{\text {th }}$ chaetiger.

about equal length. The dorsal and ventral cirri were oval to conical. Parapodia gradually increased in size towards the middle body region and decreased to posterior end (Fig. 2c-e). Notochaetae were entirely slender and capillary, while neurochaetae were spinigerous compound (Fig. 2d-f). The only posterior part of body that we found (Fig. 2c) consisted of 12 chaetigers and a pygidium without anal cirri, which were destroyed.

\section{Discussion}

The polychaetes from Lacydoniidae Bergström, 1914 family are ocassionaly collected in shelf waters of Norwegian and Barents seas (Sikorsky, personal communication), but hitherto there have been only three published records of the genus Lacydonia in the European Arctic (Fig. 1B). In the years 2003 Lacydonia sp. was collected off the northwest coast of the Kola Peninsula, in Motovsky Bay $\left(69^{\circ} 32^{\prime} \mathrm{N}, 32^{\circ} 34^{\prime} \mathrm{E}\right)$ at depths of up to $c a .200 \mathrm{~m}$ (Anisimova et al. 2010). According to the MAREANO Marbunn database (http://www.mareano.no/en/ download-data/imr/marbunn) specimens from this genus were also found in 2010 on the shelf near Troms $\varnothing$ ( $295 \mathrm{~m}$ depth, $\left.70^{\circ} 37^{\prime} \mathrm{N}, 20^{\circ} 05^{\prime} \mathrm{E}\right)$ and in the Barents Sea, south of Bear Island in 2009 (386 m depth, $\left.72^{\circ} 08^{\prime} \mathrm{N}, 16^{\circ} 32^{\prime} \mathrm{E}\right)$. Our finding is the first observation of the genus Lacydonia and species L. eliasoni in the European High Arctic. 
Literature reports on L. eliasoni are very scarce. It was first collected during the Skagerrak Expedition supervised by Prof. Sven Ekman in summer 1933, and stored at the University of Uppsala. Among this collection, two complete specimens and one fragment collected at depths of 271-487 m were identified as Lacydonia nahe miranda (ger. nahe - near) (Eliason 1962). These specimens were revised by Hartmann-Schröder (1996) and described as a new species L. eliasoni. There is just one more record of L. eliasoni, from Trondheimsfjorden in Norway (Eklöf et al. 2007), where specimens were collected between 180 and $250 \mathrm{~m}$ on Lophelia reefs (Pleijel, unpublished data). The validity of L. eliasoni was questioned by Magalhaes et al. (2012), but finally confirmed by Read and Fauchland (2016).

Hartmann-Schröder (1996) remarked on the resemblance of L. eliasoni to other species within this genus, i.e. to L. elongata Hartmann-Schröder et Rosenfeldt, 1992, which has recently been synonymized with Lacydonia papillata Ushakov, 1958 (Böggemann 2009). Our specimens of L. eliasoni did indeed look similar to L. papillata; however, they lacked the four large, papilliform dark spots on the dorsal side behind the $1^{\text {st }}$ chaetous segment reported by Ushakov (1972). Also, their dorsal and ventral cirri were oval to conical, while in holotype of L. papillata they are rudimentary, papillifirm and indistinct (Ushakov 1972). However Böggemann (2009) remarked that this pigment pattern is present in some of the preserved specimens and described the shape of dorsal and ventral cirri like globular to conical. Moreover, these two species differ in their depth range and geographic distribution. Unlike L. eliasoni, L. papillata seems to be a deepwater species as it has only been collected from depths below $1000 \mathrm{~m}$ (Paul and Menzies 1974; Alalykina 2015). It has also been reported only from locations distant from our sampling area: the Canadian Arctic and Beaufort Sea (Paul and Menzies 1974; Carey 1977), and Angola and Guinea Basin where it was identified as L. papillata (Böggemann 2009) or $L$ cf. elongata (Fiege et al. 2010).

Despite the rareness of all lacydoniids it is very unlikely that they could have been overlooked in previous benthic surveys in Svalbard. The fjords of west Spitsbergen (i.e. Kongsfjorden and Hornsund) are among the best sampled Arctic ecosystems (Piepenburg et al. 2011; Węsławski et al. 2011) and the species composition of their benthic fauna has been extensively studied. Marine ecologists from the Institute of Oceanology, Polish Academy of Sciences have visited Kongsfjorden (one of the sample locations reported in this study) every year since 1996. Altogether they have collected at least 300 benthic samples collected in all habitats and depth zones present in the fjord (Włodarska-Kowalczuk and Pearson 2004; Kaczmarek et al. 2005; Kędra et al. 2011), and have never recorded the presence of lacydoniid worms (Włodarska-Kowalczuk, personal communication). Neither has it been present in the second most extensively studied fjord, the west Spitsbergen fjord: Hornsund (Kędra et al. 2010). Also, 
the marine invertebrate species list for Svalbard waters prepared by Palerud et al. (2004), which comprises 137 published and unpublished works about marine macrofauna in Svalbard waters, does not include any lacydoniids.

It is very likely that the Lacydonia sp. specimens previously noted in the Barents Sea (Fig. 1B, cross marks) between 2003 and 2010 (Anisimova et al. 2010; MAREANO 2016) also represent L. eliasoni, as their habitat seems to be similar (type of substrata, depth range) to records from this study, and from Trondheimsfjorden (Eklöf et al. 2007) and the Skagerrak (Eliason 1962). If so, our findings document a northward expansion of this taxon along the continental shelf. This probably reflects climate changes and ecosystem evolution (Wassmann et al. 2011), especially considering that continuous habitat with no potential dispersal barriers (i.e. shelf or deep soft bottom) is expected to promote range extensions (Renaud et al. 2015). In the period of climate change, Arctic experience increased shippig that can be a vector for new species, especially with planktonic life stages (Ware et al. 2014, 2016), but as the reproduction strategy of Lacydonia specimens is unknown (if it has meroplankton larvae) it is hard to asses if this also could led to its northward range expansion.

The northward expansion of boreal species is not a new phenomenon, and the historical North Atlantic warming in the first half of $20^{\text {th }}$ century, when many species spread along the coasts of Greenland, through the North Atlantic Current into Svalbard and the Barents Sea (Renaud et al. 2008) is well documented. These expansions have involved both fishes and invertebrates. In less than 80 years Atlantic cod has been able to enhance its distribution $1200 \mathrm{~km}$ north, and benthic species have managed to spread $500 \mathrm{~km}$ north reaching the west coast of Svalbard (Renaud et al. 2008). Meanwhile along the northern coast of the Kola Peninsula the number of boreal species have increased while Arctic-type species have retreated east (Drinkwater 2006).

A contemporary temperature increase of the Atlantic surface $\left(0.6^{\circ} \mathrm{C} /\right.$ decade, Beszczyńska-Möller et al. 2012) and bottom (von Appen et al. 2015) waters flowing into the Arctic is evident. As is the influence of this increase on the composition, productivity and diversity of functional traits of both planktonic and benthic communities (Drinkwater 2006; Weydmann et al. 2014; Meyer et al. 2015). Organisms with pelagic life stages have better dispersal potential and should be the first to react to changing environments with range expansions (e.g. Wassmann et al. 2011; Carstensen et al. 2012), but species with benthic dispersal have also already succeeded in transitioning into the Arctic (Vermeij 1991; Renaud et al. 2015). In 2002 the reappearance of the blue mussel Mytilus edulis in Isfjorden after 1000 years was documented, possibly as a result of the co-occurrence of a set of favourable conditions: the increased northward transport of Atlantic Waters via the West Spitsbergen Current, winds affecting the fjord's mass transport and elevated temperature of surface waters (Berge et al. 2005). Recently, the first appearance in Svalbard waters of four echinoderm species 
(Acantotrochus mirabilis (Danielssen et Koren, 188), Asterias rubens (Linnaeus, 1758), Diplopteraster multipes (M. Sars, 1866), and Marthasterias glacialis (Linnaeus, 1758)) was found by Deja et al. (2016). Apparently, at present the European Arctic marine biota is experiencing a phase of rapid reshaping of regional biodiversity, and the monitoring of this change is crucial if we are to predict its effects on ecosystem functioning.

Acknowledgments. - We wish to thank the crews of r/v Oceania and r/v Helmer Hansen for their help during sampling. The article was prepared during doctoral studies conducted by MM at the Centre for Polar Studies, University of Silesia, Poland and the project has been financed from the funds of the Leading National Research Centre (KNOW) received by the Centre for Polar Studies for the period 2014-2018. This study was made possible by funding provided to IO PAN for the period 2013-2016 for co-funded international collaborative research based on contract no. 2930/Norway/2013/2, and funds from the Polish-Norwegian Research Programme operated by the National Centre for Research and Development under the Norwegian Financial Mechanism 2009-2014 in the frame of Project Contract No Pol-Nor/201992/93/2014 (DWARF). This work is also a contribution to funds from Norwegian Research Council (Marine Night, NRC 226417).

\section{References}

AlaLYKINA I. 2013. Preliminary data on the composition and distribution of polychaetes in the deep-water areas of the north-western part of the Sea of Japan. Deep-Sea Research Part II: Topical Studies in Oceanography 86-87: 164-171.

ALALYKINA I. 2015. Polychaete composition from the abyssal plain adjacent to the Kuril-Kamchatka Trench with the description of a new species of Sphaerephesia (Polychaeta: Sphaerodoridae). Deep Sea Research II 111: 166-174.

ANISIMOVA N.A., JøRGENSEN L.L., LYUBIN P.A. and MANUSHIN I.E. 2010. Mapping and monitoring of benthos in the Barents Sea and Svalbard waters: results from the joint Russian-Norwegian benthic programme 2006-2008. IMR-PINRO Joint Report Series 1: 1-116.

Berge J., Johnsen G., Nilsen F., Gulliksen B. and Slagstad D. 2005. Ocean temperature oscillations enable reappearance of blue mussels Mytilus edulis in Svalbard after a 1000 year absence. Marine Ecology Progress Series 303: 167-175.

BeszCZyŃSKA-Möller A., FAHrbach E., Schauer U. and HANSEn E. 2012. Variability in Atlantic water temperature and transport at the entrance to the Arctic Ocean, 1997-2010. ICES Journal of Marine Science: Journal du Conseil 69: 852-863.

BLAKE J.A. 1994. Family Lacydoniidae Bergström, 1914. In: J.A. Blake and B. Hilbig (eds) Taxonomic Atlas of the Santa Maria Basin and Western Santa Barbara Channel. Volume 4. The Annelida Part 1. Oligochaeta and Polychaeta: Phyllodocida (Phyllodocidae to Paralacydoniidae). Santa Barbara Museum of Natural History, Santa Barbara: 187-195.

BöGGEMANN M. 2009. Polychaetes (Annelida) of the abyssal SE Atlantic. Organisms Diversity and Evolution 9: 251-428.

Borja A., Franco J. and Perez V. 2000. A marine Biotic Index to establish the ecological quality of soft-bottom benthos within European estuarine and coastal environments. Marine Pollution Bulletin 40: 1100-1114. 
CAREY A. 1977. Environmental Assessment of the Alaskan Continental Shelf. Annual Reports of Principal Investigators for the year ending March 1977 Vol 6. Receptors - Fish, Littoral, Benthos. Department of Commerce, National Oceanic and Atmospheric Administration, Environmental Research Laboratory, Boulder: 858 pp.

CARstensen J., WeYdMAnN A., OlszewsKA A. and KWAŚNIEWSKi S. 2012. Effects of environmental conditions on the biomass of Calanus spp. in the Nordic Seas. Journal of Plankton Research 34: 951-966.

ÇinAR M.E. and DAGLi E. 2013. Polychaetes (Annelida: Polychaeta) from the Aegean and Levantine coasts of Turkey, with descriptions of two new species. Journal of Natural History 47: 911-947.

ÇInAR M.E., DAGLI E. and AÇIK S. 2011. Annelids (Polychaeta and Oligochaeta) from the Sea of Marmara, with descriptions of five new species. Journal of Natural History 45: 2105-2143.

DAYTON P.K., MoRdidA B.J. and BACON F. 1994. Polar Marine Communities. American Zoologist 34: 90-99.

Deja K., WęsŁaWski J.M., Borszcz T., WŁodarska-Kowalczuk M., Kukliński P., BaŁazy P. and KWIATKOWSKa P. 2016. Recent distribution of Echinodermata species in Spitsbergen coastal waters. Polish Polar Research 37: 511-526.

DRINKWATER K.F. 2006. The regime shift of the 1920s and 1930s in the North Atlantic. Progress in Oceanography 68: 134-151.

EKLÖF J., PleiJel F. and SundBERG P. 2007. Phylogeny of benthic Phyllodocidae (Polychaeta) based on morphological and molecular data. Molecular Phylogenetics and Evolution 45: 261-271.

ELIASON A. 1962. Die Polychaeten der Skagerak-Expedition 1933. Zoologiska bidrag från Uppsala 33: 207-293.

Fiege D., RAmey P.A. and EbBe B. 2010. Diversity and distributional patterns of Polychaeta in the deep South Atlantic. Deep-Sea Research Part I: Oceanographic Research Papers, 57: $1329-1344$.

Fleischer D., Schaber M. and PiePenburg D. 2007. Atlantic snake pipefish (Entelurus aequoreus) extends its northward distribution range to Svalbard (Arctic Ocean). Polar Biology 30: $1359-1362$.

FOLK R. and WARD W. 1957. Brazos River bar: a study in the significance of grain size paramet. Journal of Sedimentary Petrology 27: 3-26.

HARTMAN O. 1964. Polychaeta Errantia of Antarctica. Antarctic Research Series 3: 1-131.

HARTMAN O. and FAUCHALD K. 1971. Deep-water benthic polychaetous annelids off New England to Bermuda and other North Atlantic Areas. Part II. Allan Hancock Monographs in Marine Biology 6: 1-327.

Hartmann-SchröDer G. 1996. Annelida, Borstenwürmer, Polychaeta. Die Tierwelt Deutschlands und der angrenzenden Meeresteile nach ihren Merkmalen und nach ihrer Lebensweise, 2. Auflage 58, VEB Gustav Fischer Verlag, Jena: 648 pp.

HARTMANN-SChRÖDER G. and Rosenfelt P. 1992. Die Polychaeten der "Polarstern" - Reise ANT V/1 in die Antarktis 1986. Teil 1: Euphrosinidae bis Iphitimidae. Mitteilungen aus dem Hamburgischen Zoologischen Museum und Institut 89: 85-124.

Hop H., Falk-Petersen S., Svendsen H., Kwasniewski S., Pavlov V., Pavlova O. and SøREIDE J.E. 2006. Physical and biological characteristics of the pelagic system across Fram Strait to Kongsfjorden. Progress in Oceanography 71: 182-231.

KACZMAREK H., KowAlCZUK M.W., LegEŻYNSKA J., and ZAJĄCZKOWSKi M. 2005. Shallow sublittoral macrozoobenthos in Kongsfjord, West Spitsbergen, Svalbard. Polish Polar Research 26: $137-155$. 
Kędra M., Gromisz S., JaskuŁa R., Legeżyńska J., Maciejewska B., Malec E., OpanowSKi A., OstrowsKa K., WŁodarsKa-KowalcZuK M. and WęSŁaWsKi J.M. 2010. Soft bottom macrofauna of an All Taxa Biodiversity Site: Hornsund $\left(77^{\circ} \mathrm{N}\right.$, Svalbard). Polish Polar Research 31: 309-326.

KĘDRA M., LEGEŻYŃSKA J. and WALKUSZ W. 2011. Shallow winter and summer macrofauna in a high Arctic fjord $\left(79^{\circ} \mathrm{N}\right.$, Spitsbergen). Marine Biodiversity 41: 425-439.

Kędra M., Renaud P.E., Andrade H., GoszczKo I. and Ambrose W.G. 2013. Benthic community structure, diversity, and productivity in the shallow Barents Sea bank (Svalbard Bank). Marine Biology 160: 805-819.

KRÖGER K. and ROWDEN A.A. 2008. Polychaete assemblages of the northwestern Ross Sea shelf: Worming out the environmental drivers of Antarctic macrobenthic assemblage composition. Polar Biology 31: 971-989.

LAUBIER L. 1975. Lacydonia laureci sp. n., annélide polychète nouvelle de l'étage abyssal de méditerranée orientale. Vie et Milieu 25: 75-82.

MagalHÃES W.F., BAILEY-BRock J.H. and Rizzo A.E. 2012. Lacydonia quadrioculata, a new lacydoniid (Polychaeta: Phyllodocida) from Oahu, Hawaii. Zootaxa 3589: 65-76.

MeYer K.S., SweETMAn A.K., Young C.M. and REnAud P.E. 2015. Environmental factors structuring Arctic megabenthos - a case study from a shelf and two fjords. Frontiers in Marine Science 2: 1-14.

Nelson R.J., CARMack E.C., MCLaughlin F.A. and CoOper G.A. 2009. Penetration of pacific zooplankton into the western arctic ocean tracked with molecular population genetics. Marine Ecology Progress Series 381: 129-138.

Palerud R., Gulliksen B., Brattegard T., Sneli J.-A. and VAder W. 2004. The marine macroorganisms in Svalbard waters. In: P. Prestrud, H. Strøm and H.V. Goldman H.V. (eds) A catalogue of terrestrial and Marine Animals of Svalbard. Norwegian Polar Institute, Tromsø: 5-56.

PAUL A.Z. and MENZIES R.J. 1974. Benthic ecology of the high arctic deep sea. Marine Biology 27: 251-262.

Piepenburg D., Archambault P., Ambrose W.G., Blanchard A.L., Bluhm B.A., Carroll M.L., Conlan K.E., Cusson M., Feder H.M., Grebmeier J.M., Jewett S.C., Lévesque M., Petryashev V.V., SeJr M.K., Sirenko B.I. and WŁodarska-KowalczuK M. 2011. Towards a pan-Arctic inventory of the species diversity of the macro- and megabenthic fauna of the Arctic shelf seas. Marine Biodiversity 41: 51-70.

Renaud P.E., CARroll M.L. and Ambrose W.G.J. 2008. Effects of Global Warming on Arctic Sea-Floor Communities and Its Consequences for higher trophic levels. In: Duarte C.M. (ed.) Impacts of Global Warming on Polar Ecosystems. Fundación BBVA, Bilbao: 141-177.

Renaud P.E., SeJR M.K., Bluhm B.A., SirenKo B. and EllingSen I.H. 2015. The future of Arctic benthos: Expansion, invasion, and biodiversity. Progress in Oceanography 139: 244-257.

Renaud P.E., WŁodarska-Kowalczuk M., Trannum H., Holte B., WęsŁawski J.M., CoCHRANE S., DAhle S. and Gulliksen B. 2007. Multidecadal stability of benthic community structure in a high-Arctic glacial fjord (van Mijenfjord, Spitsbergen). Polar Biology 30: 295-305

Rizzo A.E., MagalHães W.F., and Santos C.S.G. 2015. Lacydoniidae Bergström, 1914 (Polychaeta) in the South Atlantic: morphology, three new species and five new records. Journal of the Marine Biological Association of the United Kingdom 96: 1-21.

Rouse G. and PleiJel F. 2001. Polychaetes. Oxford University Press, Oxford: 354 pp.

SARDÁ R. 1985. Anélidos poliquetos del Estrecho de Gibraltar. I. Amphinomida, Spintherida y Phillodocida. Miscellania Zoologica 9: 65-78. 
Southern R. 1914. Part 47. Archiannelida and Polychaeta. Proceedings of the Royal Irish Academy. Section A: Mathematical and Physical Sciences 31: 47.1-47.160.

Thomas D., Fogg G., Convey P., Fritsen C., Gili J.M., Gradinger R., Laybourn-Parry J., REID K. and WALTON D.W.H. 2008. The Biology of Polar Regions. Oxford University Press Oxford, New York: 416 pp.

Uebelacker J. and Johnson P. 1984. Taxonomic Guide to the Polychaetes of the Northern Gulf of Mexico. Vol 5. Department of the Interior, Metairie, Lousiana: $85 \mathrm{pp}$.

USHAKOV P.V. 1972. Fauna of the USSR. Polychaetes. Vol. I. Polychaetes of the suborder Phyllodociformia of the Polar Basin and the northwestern part of the Pacific (Families Phyllodocidae, Alciopidae, Tomopteridae, Typhloscolecidae, and Lacydoniidae). Akademia Nauk SSSR, Zoological Institute New Series 102: 1-271 [in Russian].

VERMEIJ G. 1991. Anatomy of an invasion: the trans-Arctic interchange. Paleobiology 17: 281-307.

von ApPen W.J., Schauer U., Somavilla R., Bauerfeind E. and BeszCZYNSKA-Möller A. 2015. Exchange of warming deep waters across Fram Strait. Deep-Sea Research Part I: Oceanographic Research Papers 103: 86-100.

Ware C., Berge J., Jelmert A., Olsen S.M., Pellissier L., Wisz M., Kriticos D., Semenov G., KWAŚNIEWSKI S. and ALSOS I.G. 2016. Biological introduction risks from shipping in a warming Arctic. Journal of Applied Ecology 53: 340-349.

Ware C., Berge J., Sundet J.H., KirkPatrick J.B., CoutTS A.D.M., Jelmert A., Olsen S.M., Floerl O., Wisz M.S. and Alsos I.G. 2014. Climate change, non-indigenous species and shipping: Assessing the risk of species introduction to a high-Arctic archipelago. Diversity and Distributions 20: 10-19.

Wassmann P., DUarte C.M., Agustí S. and SeJR M.K. 2011. Footprints of climate change in the Arctic marine ecosystem. Global Change Biology 17: 1235-1249.

Weydmann A., Carstensen J., GoszczKo I., DMoch K., Olszewska A. and Kwaśniewski S. 2014. Shift towards the dominance of boreal species in the Arctic: Inter-annual and spatial zooplankton variability in the West Spitsbergen Current. Marine Ecology Progress Series 501: $41-52$.

WęSŁAWSKI J.M., Kendall M.A., WŁodARSKA-KowalCZUK M., IKEN K., KĘDRA M., LEGEZYNSKA J. and SEJR M.K. 2011. Climate change effects on Arctic fjord and coastal macrobenthic diversity-observations and predictions. Marine Biodiversity 41: 71-85.

WŁodARSKa-KowalcZUK M. and PeArson T.H. 2004. Soft-bottom macrobenthic faunal associations and factors affecting species distributions in an Arctic glacial fjord (Kongsfjord, Spitsbergen). Polar Biology 27: 155-167.

WŁodarska-KowalczuK M., Renaud P.E., WęSŁaWski J.M., Cochrane S.K.J. and DenisenKO S.G. 2012. Species diversity, functional complexity and rarity in Arctic fjordic versus open shelf benthic systems. Marine Ecology Progress Series 463: 73-87.

Received 25 November 2016

Accepted 6 February 2017 